\title{
Implications of effluent organic matter and its hydrophilic fraction on zinc(II) complexation in rivers under strong urban pressure: Aromaticity as an inaccurate indicator of DOM-metal binding
}

\author{
Yoann Louis a,b, Benoît Pernet-Coudrier ${ }^{\mathrm{a}, \mathrm{c}, \mathrm{d}}$, Gilles Varrault ${ }^{\mathrm{a}, *}$ \\ a Université Paris-Est, LEESU (UMR MA 102), UPEC, UPEMLV, ENPC, AgroParisTech, 94010 Créteil, France \\ b Laboratoire LGCIE, Université de Lyon, INSA-Lyon, Bât. Carnot, 9 rue de la Physique, 69621 Villeurbanne, France \\ ' Université Européenne de Bretagne, Rennes, France \\ ' Université de Bretagne Occidentale, IUEM, Lemar, UMR CNRS 6539, rue Dumont D'Urville, 29280 Plouzané, France
}

\section{H I G H L I G H T S}

- For the first time, hydrophilic organic matter has been considered regarding $\mathrm{Zn}$

- Effluent organic matter shown high binding capacities and constants regarding $\mathrm{Zn}$

- Hydrophilic organic matter bound more zinc than natural humics and fulvics

- Specific UV Absorbance is not the right indicator of Zn-DOM binding

- BLM would need better indicator than SUVA to predict Zn bioavailability \& toxicity

\section{A R T I C L E I N F O}

\section{Article history:}

Received 20 December 2013

Received in revised form 24 April 2014

Accepted 29 April 2014

Available online 5 June 2014

Editor: C.E.W. Steinberg

\section{Keywords:}

Dissolved organic matter

Metal speciation

Stripping voltammetry

Zinc

Urban

Wastewater
G R A P H I C A L A B S T R A C T
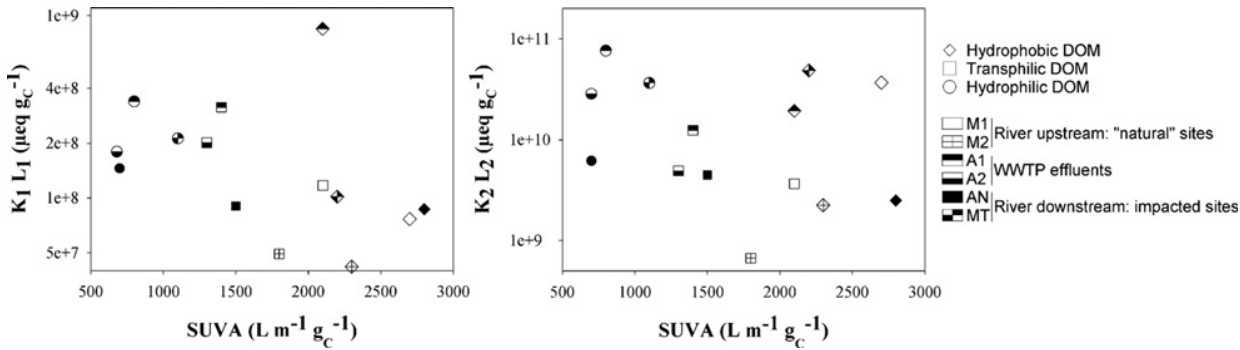

\begin{abstract}
A B S T R A C T
The zinc binding characteristics of dissolved organic matter (DOM) fractions from the Seine River Basin were studied after being separated and extracted according to their polarity: hydrophobic, transphilic, and hydrophilic. The applied experimental methodology was based on a determination of labile zinc species by means of differential pulse anodic stripping voltammetry (DPASV) at increasing concentrations of total zinc on a logarithmic scale and at fixed levels of: $\mathrm{pH}$, ionic strength, and temperature. Fitting the DOM fractions with two discrete classes of ligands successfully allowed determining the conditional zinc binding constants $\left(\mathrm{K}_{\mathrm{i}}\right)$ as well as total ligand density $\left(L_{i T}\right)$. The binding constants obtained for each DOM fraction were then compared and discussed with respect to the hydrophobic/hydrophilic nature and sample origin. Results highlighted a strong complexation of zinc to the effluent organic matter and especially the most hydrophilic fraction, which also displayed a very low specific UV absorbance. Although the biotic ligand model takes into account the quality of DOM through UV absorbance in the predictions of metal bioavailability and toxicity, this correction is not efficient for urban waters.
\end{abstract}

(c) 2014 Elsevier B.V. All rights reserved.

\footnotetext{
* Corresponding author. Tel.: +3314517 1631 .

E-mail addresses: yoann.louis@insa-lyon.fr (Y. Louis), benoit.pernet-coudrier@univbrest.fr (B. Pernet-Coudrier), varrault@u-pec.fr (G. Varrault).
}

\section{Introduction}

Zinc is widely used in urban areas, especially for infrastructure such as buildings or street furniture. In central Paris, where architectural rules protecting historical monuments and their environment prevent any changes over many years (Gromaire et al., 2002), roughly 40\% of 
all roofing surfaces are covered with rolled zinc. Hence, the atmospheric corrosion of roofing materials (roofing tiles, gutters, downspouts) has been identified as a major source of zinc, cadmium, lead and copper in wet weather flows (Gromaire et al., 2001; Robert-Sainte et al., 2009). This situation has led to extremely high concentrations of zinc (up to $7000 \mu \mathrm{g} \mathrm{L}^{-1}$ ) in roof runoff (Robert-Sainte et al., 2009), which furthermore is being discharged into the Seine River (Thevenot et al., 2007).

Dissolved organic matter (DOM) exerts a strong influence on zinc speciation in water due to significantly lowering the free $\mathrm{Zn}^{2+}$ levels relative to the total dissolved $\mathrm{Zn}$ (Cheng and Allen, 2006; Cheng et al., 2005), which in turn serves to modulate its bioavailability. In aquatic systems, DOM is a ubiquitous mixture of compounds resulting from diverse processes that can be categorized as either degradation or primary production. In an urbanized aquatic system, DOM may also be discharged from the wastewater treatment plant and/or produced locally from the large primary production induced by these discharges. These phenomena account for the high hydrophilic and low aromatic fractions of DOM within urbanized aquatic systems (Imai et al., 2002; Ma et al., 2001; Pernet-Coudrier et al., 2011b), compared to natural waters where the hydrophobic acid fraction of DOM, humics and fulvics likely constitute the predominant fraction (Martin-Mousset et al., 1997). Some studies conducted on urban wastewater (Buzier et al., 2006a; Buzier et al., 2006b; Sarathy and Allen, 2005) have emphasized the strong affinity of the hydrophilic fraction for metal ions. Hydrophilic fractions from wastewater discharges were also recently shown to play a similar role as fulvic substances during an acute toxicity test on copper with Daphnia Magna (Pernet-Coudrier et al., 2008). Moreover, recent investigations with $\mathrm{Pb}, \mathrm{Hg}, \mathrm{Cu}, \mathrm{Cd}$ and $\mathrm{Ni}$ have demonstrated the higher metal binding ability of hydrophilic DOM compared to humic substances (Baken et al., 2011; Muresan et al., 2011; Pernet-Coudrier et al., 2011a). Evidence thus suggests that when computing trace metal speciation within "urbanized" water bodies, it is essential to consider the binding capabilities of hydrophilic DOM as well. The metal binding ability of hydrophilic DOM has not yet been taken into account in the widely used biotic ligand model (BLM), used to predict metal toxicity (Di Toro et al., 2001). The variability in DOM quality is in fact not considered as an especially critical parameter. BLM may eventually be corrected for DOM aromaticity with a specific UV absorbance (SUVA), in assuming that only fulvic acids are active in zinc complexation (De Schamphelaere et al., 2004). This hypothesis might be reliable in a natural aquatic system; such is not the case however in an anthropized aquatic system, where fulvic acids are not predominant (Baken et al., 2011). To better assess the level of zinc ecotoxicity in water, a comprehensive knowledge of $\mathrm{Zn}$-DOM binding properties is required, especially in urbanized areas where $\mathrm{Zn}$ is widely present and where the DOM composition is capable of varying widely from one source to the next.

Among all the analytical methods available to determine chemical speciation (Batley et al., 2004), anodic stripping voltammetry (ASV) is an appealing one that satisfies the requirements of both sensitivity and selectivity. In addition, ASV can provide useful information on the DOM-metal association (complexing parameters) needed to run the mathematical speciation programs (Coale and Bruland, 1990; Garnier et al., 2004a; Muller, 1999). According to a number of studies, the only limitation with ASV for metal speciation is this technique's kinetic dependence (van Leeuwen et al., 2005), whereby some complexes may dissociate and become electro-labile during the accumulation period, which could then lead to underestimating the complexing parameters. This limitation however might also be favorable given that such processes may be occurring on the biological cell membranes as well (van Leeuwen et al., 2005). According to DOM structural heterogeneity, mono- and multi-dentate ligands could be expected (Tipping, 1998). Yet no convincing evidence has been found to corroborate that models with multi-dentate ligands perform any better than single-site models. In practice, it is generally valid to assume a $1: 1$ stoichiometry of the complexation reaction between $\mathrm{Zn}$ and DOM, and moreover a number of studies have shown that this assumption is reasonable when modeling metal ion and NOM complexation (Bugarin et al., 1994; Cheng and Allen, 2006; Tipping, 1998). In this study therefore, DOM binding properties towards zinc have been modeled using a discrete distribution of mono-dentate binding ligands $\left(L_{i}\right)$, each defined by 2 parameters: a total site concentration $\left(L_{i T}\right)$, and a conditional stability constant $\left(K_{Z n L i}\right)$ (Garnier et al., 2004a; Sposito, 1981).

In a previous study (Pernet-Coudrier et al., 2011b), the DOM isolated from both upstream and downstream Paris, as well as from the effluents of Paris' largest regional wastewater treatment plant (WWTP), was fractionated according to polarity criteria. The aim of this study is to characterize the interaction between these DOM fractions and zinc using differential pulse anodic stripping voltammetry (DPASV) in conjunction with a discrete model. During a subsequent step, these parameters will be compared for various extracted fractions (hydrophobic, transphilic and hydrophilic) from several different areas (urban and natural).

\section{Materials and methods}

\subsection{Sampling sites and DOM extraction}

Four sites located within the Seine River Basin (see Fig. 1), upstream (Méry-sur-Marne) and downstream Paris (Andrésy and Méricourt), along with treated effluent from the largest wastewater treatment plant (WWTP, also called Seine-Aval) within the Paris Metropolitan Area, were sampled during various dry weather periods between April 2006 and July 2007. Sampling site characteristics are presented in Table 1.

This WWTP (labeled A1 and A2) was chosen for the present study due to the fact that it collects over $60 \%$ of all dry weather flows (combined sewer) from Paris and the surrounding suburbs (approx. 8 million population). This WWTP is the biggest in France, with a treated wastewater volume of about $1.6 \cdot 10^{\wedge 6} \mathrm{~m}^{3} /$ day. Such effluents are highly representative of Paris discharge and are treated at this WWTP by means of primary settling and aerobic activated sludge. The Méry-surMarne site (labeled M1 and M2) is located upstream from metropolitan Paris on the Marne River. Due to low population density in the catchment, this site was chosen as a reference; given its limited impact from urban discharges, Méry-sur-Marne could be considered as a "natural" reference site. Samples M1 and M2 were extracted in winter and summer, respectively. The Andrésy site (labeled AN) is located $\sim 5 \mathrm{~km}$ downstream of the Seine-Aval WWTP; given the fact that WWTP effluents are well mixed with the Seine River at this spot, Andrésy was thus chosen as a highly anthropized site. The Méricourt site (labeled MT) is located further downstream at $\sim 50 \mathrm{~km}$ from Andrésy; this site was selected to study the influence of travel time on modifications to the physicochemical properties of DOM.

The exhaustive DOM extraction process has been described in detail in Pernet-Coudrier et al. (2011a, 2011b). Surface waters were briefly filtered, concentrated in-line and on-site by reverse osmosis, and then acidified and fractionated on Amberlite DAX-8 resins and Supelite $\mathrm{XAD}-4$ in the laboratory. This procedure allows for fractionating DOM into three fractions according to polarity criteria: hydrophobic (HPO), transphilic (TPI), and hydrophilic (HPI). The HPI fractions, which are those not absorbed on the resins, were purified through various zeotropic distillations, salt precipitations and filtrations with cationic exchange resins. Lastly, the eluates were freeze-dried and stored for subsequent use.

\subsection{Chemicals and instrumentation}

All vessels used were cleaned with 10\% nitric acid (Fisher Scientific, analytical grade) and rinsed with ultra-pure deionized water (>18 M $\Omega$ ). Zinc solutions $\left(10,100\right.$ and $\left.1000 \mu \mathrm{mol} \mathrm{L}^{-1}\right)$ used for titration were prepared from zinc standard ( $1 \mathrm{~g} \mathrm{~L}^{-1}$, Merck). Samples were acidified, as needed, using $65 \% \mathrm{HNO}_{3}$ (Fisher, Optima). 


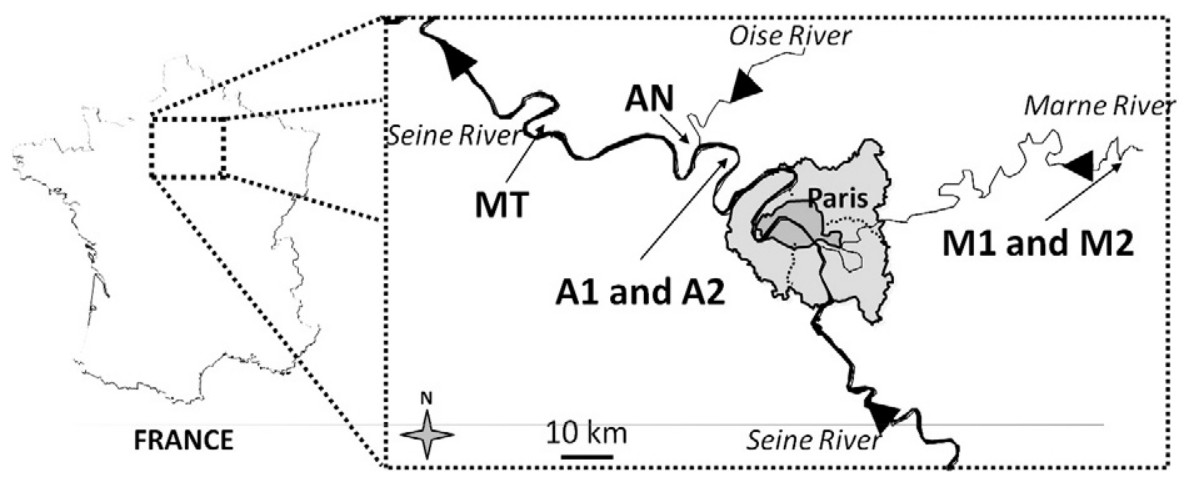

Fig. 1. Map of the sampling sites.

All voltammetric measurements were carried out with a PGSTAT12 voltammetric analyzer (Metrohm, Switzerland) controlled by GPES 4.9 software (Eco Chemie) and coupled with the 663VA Stand threeelectrode system (Metrohm, Switzerland). The working electrode was a static mercury drop electrode (SMDE) (size: 1, cross-section: $0.25 \mathrm{~mm}^{2}$ ). Potentials were given relative to the $\mathrm{Ag} \mid \mathrm{AgCl}$ (sat. $\mathrm{KCl}$ ) reference electrode. A glassy carbon electrode was used as a counter electrode. $30 \mathrm{~mL}$ of a sample, supported in a PFA electrochemical cell (Metrohm), was stirred with a Teflon rotating stirrer at $3000 \mathrm{rpm}$. Dissolved oxygen was removed from the solution prior to analysis by purging with ultra-pure nitrogen for at least $15 \mathrm{~min}$. To exclude sample evaporation, a water-saturated nitrogen blanket was maintained above the solution surface throughout the experiment. All experiments were performed at room temperature $\left(20^{\circ} \pm 2{ }^{\circ} \mathrm{C}\right)$. Three automatic burettes (Cavro XE 1000 syringe pumps, Tecan, Switzerland) were introduced to automate zinc titration.

The conditions applied to DPASV measurements of electro-labile zinc were: a pulse amplitude of $25 \mathrm{mV}$, a potential step increment of $2.5 \mathrm{mV}$, a time interval between pulses of $0.1 \mathrm{~s}$ with a pulse duration of $0.05 \mathrm{~s}$, and a quiescent period of $5 \mathrm{~s}$. The potential was scanned from $-1.1 \mathrm{~V}$ to $-0.7 \mathrm{~V}$. The critical point in this protocol is the deposition time, which has been divided into two parts: i) $120 \mathrm{~s}$ ( or $60 \mathrm{~s}$ ) at a deposition potential $\left(E_{\text {dep }}\right)$ of $-1.05 \mathrm{~V}$; and ii) $2 \mathrm{~s}$ ( or $1 \mathrm{~s}$ ) at a deposition potential of $-1.6 \mathrm{~V}$. This last strong negative potential allows for the removal of a number of surface-active substances capable of being adsorbed at the electrode surface and producing interference during the stripping step (Louis et al., 2008). Moreover, the deposition potential of $-1.05 \mathrm{~V}$ was precisely determined according to the pseudopolarography technique (Nicolau et al., 2008) for all samples in order to measure with the available higher sensitivity just the most electro-labile zinc.

Total dissolved zinc concentrations $\left(\mathrm{Zn}_{\mathrm{T}}\right)$ were determined using ICP-MS (X Series, Thermo Electron Corporation) controlled by the Thermo Plasmalab software $\left(\mathrm{LOQ}=10 \mathrm{nmol} \mathrm{L}^{-1}\right)$.

To measure and control pH, a Titrando 835 titrator (Metrohm, Switzerland), controlled via the Tiamo software (Metrohm, Switzerland), was used. The combined pH electrode used (Metrohm) was calibrated daily with pH buffer solutions (Fisher, 4.01, 7.01, 10.01).

\subsection{Experiments and data modeling}

Due to small available amount, 4 DOM fractions were not analyzed (HPI M1 and M2, HPO A2 and TPI MT). All samples were prepared at $25 \mathrm{mg} \mathrm{L}^{-1}$ (dry mass) of organic matter, which lies within the range of environmental concentrations. To work at constant $\mathrm{pH}$, the PIPPS (Calbiochem) non-complexing "better" buffer (Kandegedara and Rorabacher, 1999; Soares and Conde, 2000) was added to the sample at a final concentration of $5 \mathrm{mmol} \mathrm{L}^{-1}$, then adjusted to $\mathrm{pH} 8$ with $\mathrm{KOH}$ (Merck, Suprapur) and left overnight to both ensure proper dissolution and reach $\mathrm{pH}$ equilibrium. $\mathrm{KNO}_{3}$ (Merck, Suprapur), with a final concentration of $10 \mathrm{mmol} \mathrm{L}^{-1}$, was also added in order to establish the ionic strength.

As a next step, $30 \mathrm{~mL}$ of each sample was titrated using a logarithmic scale titration (Garnier et al., 2004b) covering a zinc concentration range from about $50 \mathrm{nmol} \mathrm{L}^{-1}$ to $10 \mu \mathrm{mol} \mathrm{L}^{-1}$. Let's note at this point that no intermetallic compound (Nicolau et al., 2008) of zinc with copper is expected in this study due to the relatively low copper content of samples. Deposition times of $120 \mathrm{~s}$ and $60 \mathrm{~s}$ were selected for each titration point in order to improve the sensitivity of these techniques for low and high metal concentrations, respectively. After each addition, DPASV measurements using both deposition times (120 s and $60 \mathrm{~s}$ ) were repeated 5 times to reach equilibrium. Generally speaking, the last two measurements served to determine the binding parameters. For each sample, voltammograms obtained for at least 13 zinc additions were used.

For all voltammetric experiments, the peak height was adopted as a characteristic signal value. The resultant DPASV peak heights were integrated according to the tangent fit technique (Omanović et al., 2010), which was convenient given the baseline shape obtained with zinc measurements at $\mathrm{pH}$ 8. Corresponding electro-labile zinc concentrations were calculated from the sensitivity $\left(0.182 \mathrm{nA} \mathrm{L} \mathrm{nmol}{ }^{-1}\right.$ and $0.094 \mathrm{nA} \mathrm{L} \mathrm{nmol}{ }^{-1}$ respectively for deposition times of $120 \mathrm{~s}$ and $60 \mathrm{~s}$ ) derived at the end of the logarithmic titration and for a blank sample under the same conditions of $\mathrm{pH}$, ionic strength and buffer, but without any organic matter.

DOM binding properties towards zinc were modeled using a discrete distribution of mono-dentate binding ligands $\left(L_{i}\right)$, each of which was

Table 1

Location and dates of sampling and main physico-chemical characteristics of the sampled water.

\begin{tabular}{|c|c|c|c|c|c|c|c|c|c|c|}
\hline Sampling site & Symbol & Date & Flow $\left(\mathrm{m}^{3} \mathrm{~s}^{-1}\right)$ & Temperature $\left({ }^{\circ} \mathrm{C}\right)$ & $\mathrm{pH}$ & Conductivity $\left(\mu \mathrm{S} \mathrm{cm}^{-1}\right)$ & $\mathrm{DOC}\left(\mathrm{mg} \mathrm{C} \mathrm{L}^{-1}\right)$ & HPO (\% of DOC) & TPI (\% of DOC) & HPI (\% of DOC) \\
\hline \multirow{2}{*}{ Méry/Marne } & M1 & $30 / 01 / 07$ & 80 & 7 & 8.5 & 560 & 2.0 & 69 & 21 & 10 \\
\hline & M2 & $27 / 06 / 07$ & 35 & 19 & 8.3 & 517 & 2.0 & 62 & 15 & 23 \\
\hline \multirow[t]{2}{*}{ Seine-Aval WWTP } & $\mathrm{A} 1$ & $06 / 04 / 06$ & $\approx 20$ & 17 & 7.8 & 1580 & 38.7 & 35 & 20 & 45 \\
\hline & A2 & $15 / 12 / 06$ & $\approx 20$ & 14 & 8.1 & 1261 & 17.4 & 37 & 21 & 42 \\
\hline Andrésy & An & $29 / 06 / 07$ & $120^{\mathrm{a}}$ & 18 & 7.7 & 606 & 4.1 & 42 & 23 & 35 \\
\hline Méricourt & Mt & $03 / 07 / 07$ & $120^{\mathrm{a}}$ & 20 & 7.6 & 625 & 4.0 & 51 & 18 & 31 \\
\hline
\end{tabular}

a Measured in Paris (Austerlitz). 
defined by 2 parameters: total site concentration $\left(L_{i T}\right)$, and conditional stability constant $\left(K_{Z n L}, i\right)$ (Garnier et al., 2004a; Sposito, 1981). The association between zinc and a mono-dentate ligand $\left(L_{i}\right)$ can be described by the following equation:

$\mathrm{Zn}^{2+}+L_{i} \stackrel{K_{\mathrm{ZnL}}, i}{\Leftrightarrow} \mathrm{ZnL_{i } ^ { 2 + }}$ with $K_{\mathrm{ZnL}}, i=\frac{\left[Z n L_{i}^{2+}\right]}{\left[Z n^{2+}\right] \times\left[L_{i}\right]}$

where $\left[\mathrm{Zn}^{2+}\right]$ and $\left[L_{i}\right]$ are the free zinc and ligand concentration, respectively.

DPASV measurements help determine the electro-labile $\mathrm{Zn}$ fraction ( $\left.[\mathrm{Zn}]_{\text {labile }}\right)$, which mainly corresponds to inorganic metal complexes (Louis et al., 2009; Tsang et al., 2006), while the difference between a total $\left(\mathrm{Zn}_{\mathrm{T}}\right)$ and electro-labile $\mathrm{Zn}$ fraction corresponds to inert organic complexes, non-labile under the selected voltammetric parameter conditions.

For each sample, complexing parameters $\left(L_{i T}, K_{Z n L}, i\right)$ were determined by fitting a measured set of electro-labile zinc concentrations using a nonlinear fitting technique. Data were fitted using a 2-ligand model. Although the physicochemical structure of these two classes of natural ligands remains unknown, their presumed structure is often sufficient to correctly describe DOM-metal properties in the natural environment (Town and Filella, 2000).

\section{Results and discussion}

\subsection{DOM characteristics}

The exhaustive DOM characterization procedure has been described in detail in Pernet-Coudrier et al. (2011a, 2011b). Upstream from Paris, the hydrophobic fraction represents more than $60 \%$ of DOC. Due to WWTP discharge, a substantial increase in the hydrophilic fraction ( $>40 \%$ ) could be observed downstream of Paris at Andrésy, whereas the transphilic fraction always stayed around $15 \%-20 \%$ of DOC. For the A1 fractions, which correspond to EfOM (Effluent Organic Matter), as the hydrophilic character of the sample increases ( $\mathrm{HPO}<\mathrm{TPI}<\mathrm{HPI}$ ), the percentage of $\mathrm{C}$ decreases while that of $\mathrm{N}$ increases. Also, the degree of unsaturation (e.g. due to rings or multiple bonds) decreases and the average oxidation number of $C$ increases. As already shown (PernetCoudrier et al., 2011b), the hydrophilic nature of EfOM stems from the high content of polar functional groups, especially $\mathrm{N}$-containing groups (amides and amines), which is consistent with the observation of abundant proteinaceous structures by Py-GC-MS, fluorescence and FTIR.

\subsection{Zinc-DOM binding parameters}

Zinc titration was carried out with the same organic matter content (i.e. $25 \mathrm{mg} \mathrm{DOM} \mathrm{L}^{-1}$ ); results are presented in Fig. 2.

At Méry-sur-Marne (Fig. 2a), which corresponds to our natural reference area, winter fractions (HPOM1 and TPIM1) display a higher binding capacity than the summer fractions (HPOM2 and TPIM2). This higher binding capacity is confirmed and mainly explained by a higher ligand content for the HPOM1 fraction (see Table 2) as well as by a higher binding constant $\left(\log K_{Z n L, 1}\right)$ for the TPIM1 fraction. In the WWTP effluent (A1 and A2), the most binding fraction is HPOA1 with both high $\mathrm{L}_{2}$ and $\mathrm{L}_{1}$ content (Fig. $2 \mathrm{~b}$ ). The TPI fraction also displays a high content of ligand $\mathrm{L}_{1}$. However, ligand $\mathrm{L}_{2}$ of the HPIA2 fraction is a strong contributor in the binding capacity (approx. 39\%), while $\mathrm{L}_{2}$ of the other fractions barely contributed $5 \%$. These same trends are observed for sample A1, with a HPI fraction characterized by a higher $\mathrm{L}_{2}$ / $\mathrm{L}_{\mathrm{T}}$ ratio compared to the other fractions. This feature may be explained by the very high nitrogen content (Table 2 ), which has been related to the proteinaceous structures (Pernet-Coudrier et al., 2011b). The Andrésy (AN) sample, extracted downstream of Paris, reveals a higher binding capacity for the HPI fraction compared to HPO (Fig. 2c). This result is mainly indicated by higher $\mathrm{L}_{2}$ content and a higher binding constant $\left(\log K_{Z n L, 1}\right)$ of the HPI fraction. Similar to the WWTP, this HPI fraction also exhibits a higher $\mathrm{L}_{2} / \mathrm{L}_{\mathrm{T}}$ ratio (by about $12 \%$ ), which is likely explained by the WWTP being a major point source of zinc-binding ligands for the Seine River. At Méricourt (Fig. 2d), here once again, even though the HPI fraction only contains $34.2 \%$ of carbon compared to the $46.5 \%$ of HPO, it still displays higher ligand contents (both $\mathrm{L}_{2}$ and $\mathrm{L}_{1}$ ). The HPI fraction maintains a higher $\mathrm{L}_{2} / \mathrm{L}_{\mathrm{T}}$ ratio (by about $16 \%$ ), whereas the $\mathrm{L}_{2} / \mathrm{L}_{\mathrm{T}}$ ratio of the HPO fraction only comes in at $3 \%$.

In general, independent of the sampling site, the HPI fraction can systematically be characterized by higher stability constants ( $K_{1}$ and $\mathrm{K}_{2}$ ) and a higher $\mathrm{L}_{2} / \mathrm{L}_{\mathrm{T}}$ ratio compared to the other fractions. The very high $\mathrm{N}$ content (up to $12.3 \%$ ) is mainly suspected to be involved in Zn-HPI binding since N, as a proteinaceous structure, has previously been shown to strongly complex $\mathrm{Pb}, \mathrm{Hg}$ and $\mathrm{Cu}$ (Muresan et al., 2011; Pernet-Coudrier et al., 2008; Pernet-Coudrier et al., 2011a). The $\log K_{Z n L, 1}$ values, obtained here for the various fractions, are consistent with previously published conditional constants, as derived from different surface waters and basically under the same conditions for DOM (Chaminda et al., 2010; Cheng and Allen, 2006). The $\log K_{Z n L, 2}$ values produced here range between 8.43 and 9.84; these values however are higher than those found in the literature, which lie around 7 . This result can mainly be explained by a higher and more representative $\mathrm{pH}(8)$ used herein, whereas Chaminda et al. (2010) performed their titration at $\mathrm{pH} 7$, and $\mathrm{pH}$ has already been shown to be a critical parameter in the conditional zinc binding constant (Cheng and Allen, 2006). The $\mathrm{L}_{1}$ concentration values given in our study are slightly less than those published by Cheng and Allen (2006) but nearly equivalent to those obtained by Chaminda et al. (2010). $L_{2}$ concentrations from our DOM fractions are roughly one order of magnitude lower than literature values (Chaminda et al., 2010; Cheng and Allen, 2006).

\subsection{Environmental implications}

In order to assess the environmental implications related to the strong zinc binding ability of EfOM, and especially the hydrophilic fraction, zinc speciation was computed in the Seine-Aval WWTP effluent as well as in receiving water downstream of WWTP discharges. Only the binding parameters determined in this study were entered into this computation (Table 2). The competition of zinc with other trace metals or major elements for the DOM complexation was not taken into account.

\subsubsection{Seine-Aval WWTP}

Zinc speciation was computed at three different environmental zinc concentrations (Table 3), all of which were consistent with the total dissolved zinc concentrations observed in aquatic systems (Chiffoleau et al., 1994; Chiffoleau et al., 1999; Kraepiel et al., 1997; Naito et al., 2010; Zwolsman et al., 1997). The DOC concentration was set at $15 \mathrm{mg} \mathrm{C} \mathrm{L} \mathrm{L}^{-1}$, which lies within the environmental range for this WWTP effluent. The DOC distribution among the three operationallydefined fractions (HPO, TPI and HPI) was the one experimentally determined in this study (see Table 1 ).

At low zinc concentrations ( 1 and $10 \mu \mathrm{g} \mathrm{L}^{-1}$ ), approx. $60 \%$ to $75 \%$ of the total zinc was bound to the HPI fraction, which allowed controlling zinc speciation in the effluent. When considering all DOM fractions, strong binding sites $\left(L_{2}\right)$ bind more than $97 \%$ of the total zinc, whereas weak sites $\left(\mathrm{L}_{1}\right)$ are only minimally involved $(<2.7 \%)$ in the HPI fraction of DOM binding the zinc speciation. Regardless of the total zinc concentration, the transphilic fraction played just a minor role, i.e. in binding less than $10 \%$ of total zinc.

For the highest zinc concentration $\left(100 \mu \mathrm{g} \mathrm{L}^{-1}\right), \mathrm{L}_{2}$ sites are saturated; hence, around $60 \%$ of zinc is bound to $\mathrm{L}_{1}$ sites that had not been saturated with zinc. An increase in zinc concentration was also accompanied by an increase in zinc (up to $40 \%$ for $\mathrm{Zn}=100 \mu \mathrm{g} \mathrm{L}^{-1}$ ) bound to the HPO fraction. This fraction actually contains the highest 
$\log [\mathrm{Zn}]_{\text {tot }}$

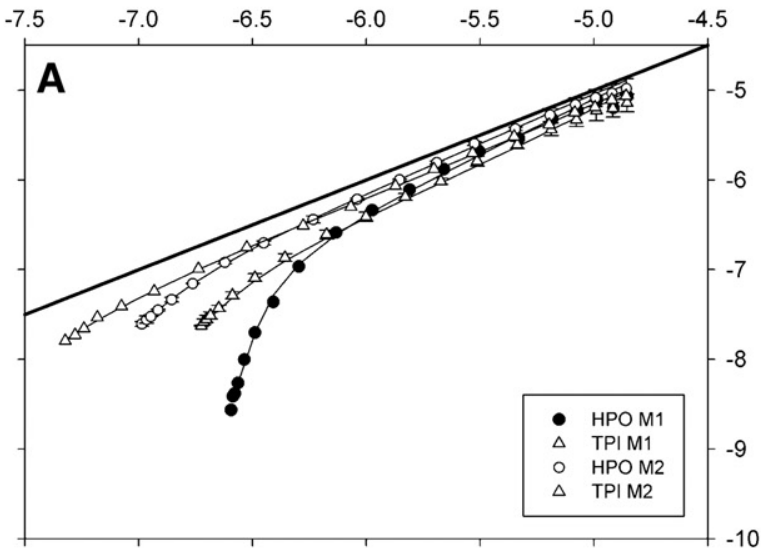

MERY SUR MARNE

$\log [\mathrm{Zn}]_{\text {tot }}$

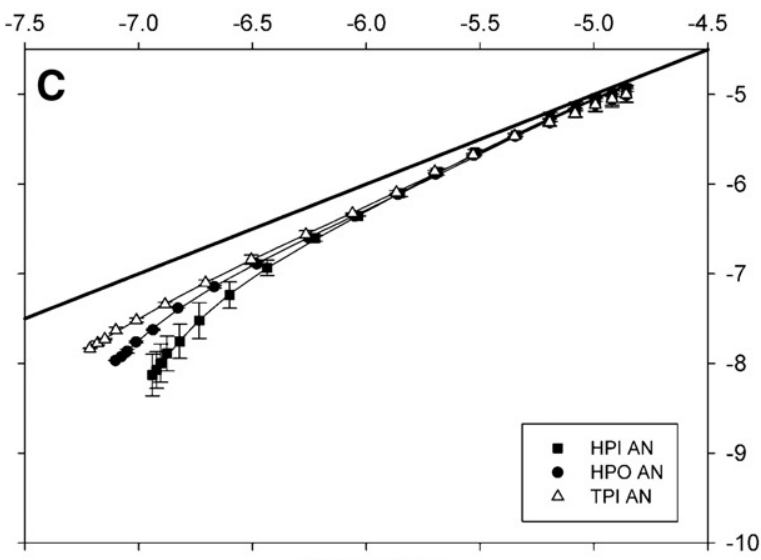

ANDRESY $\log [\mathrm{Zn}]_{\text {tot }}$

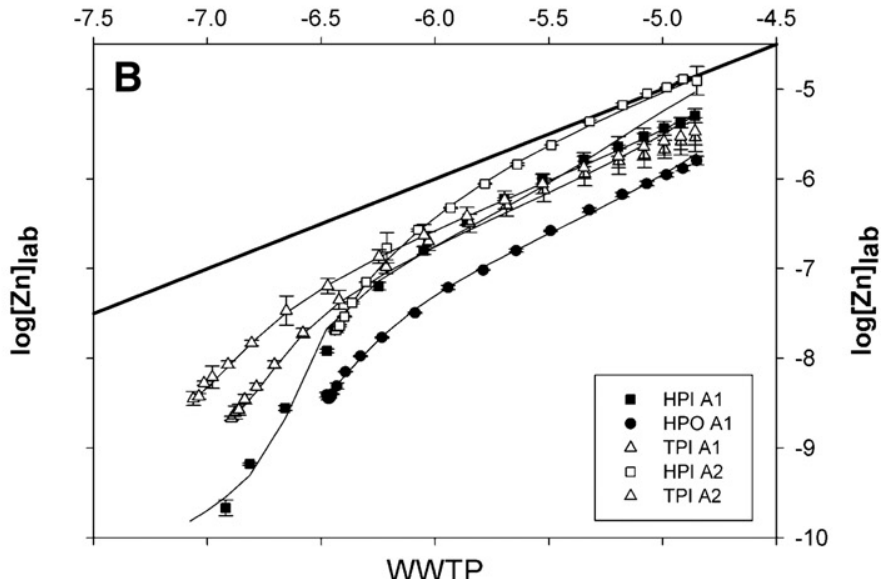

$\log [\mathrm{Zn}]_{\text {tot }}$

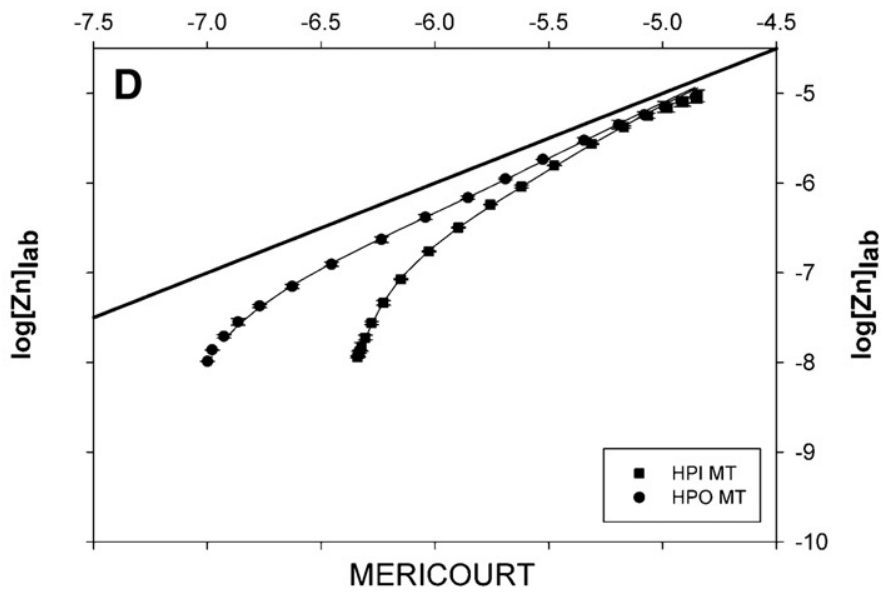

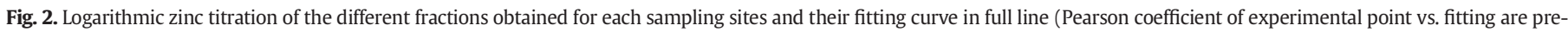
sented in Table 2). Dots represent THE average of the experimental data obtained for a $60 \mathrm{~s}$ - and 120 s-deposition time which were used for the fitting.

concentration of $\mathrm{L}_{1}$ binding sites. It is important to note that at a high zinc concentration, the inorganic zinc and especially the free zinc concentration increase considerably, from less than $1 \%$ to $13.9 \%$ of total zinc.

\subsubsection{Receiving water downstream of the Seine-Aval WWTP}

Two contrasting theoretical cases were studied. According to the first case, zinc speciation was computed with 100\% of HPOM2 (humic substances sampled upstream from Paris). This case represents the "natural" river without urban discharge. In the second case, zinc speciation was computed with a mixture of 50\% HPOM2 and 50\% HPIA1 (the main EfOM fraction). Such a mixture does not physically exist due, at least in part, to the presence of other fractions; however, it represents a low river flow period with over $40 \%$ of DOC coming from urban discharge (Matar, 2012). Computations were performed for zinc concentrations ranging from 1 to $100 \mu \mathrm{g} \mathrm{L}^{-1}$, which are considered to be environmentally relevant (Chiffoleau et al., 1994; Chiffoleau

Table 2

Conditional binding parameters obtained for various DOM fractions at $\mathrm{pH} 8$ and $\mathrm{I}=10 \mathrm{mmol} \mathrm{L}{ }^{-1}$.

\begin{tabular}{|c|c|c|c|c|c|c|c|c|c|}
\hline Site & Fraction & $\mathrm{C}(\%)$ & $\mathrm{N}(\%)$ & $\log K_{\mathrm{ZnL}, 1}$ & $\log \mathrm{K}_{\mathrm{ZnL}, 2}$ & $\mathrm{~L}_{1}\left(\mu \mathrm{mol} \mathrm{g} \mathrm{g}^{-1}\right)$ & $\mathrm{L}_{2}\left(\mu \mathrm{mol} \mathrm{g} \mathrm{g}^{-1}\right)$ & $\mathrm{L}_{\mathrm{T}}\left(\mu \mathrm{mol} \mathrm{g}_{\mathrm{C}}^{-1}\right)$ & $\begin{array}{l}\text { Pearson coefficient } \\
\text { (fitting vs. experimental) }\end{array}$ \\
\hline M1 & HPO & 45.0 & 3.0 & 5.57 & 9.14 & 206 & 27 & 233 & 0.9987 \\
\hline M1 & TPI & 46.0 & 4.8 & 5.33 & 8.43 & 544 & 14 & 558 & 0.9988 \\
\hline M2 & HPO & 40.4 & 2.8 & 5.57 & 8.46 & 112 & 8 & 120 & 0.9995 \\
\hline M2 & TPI & 47.3 & 4.9 & 4.73 & 8.48 & 916 & 2 & 918 & 0.9997 \\
\hline A1 & HPO & 53.6 & 5.7 & 5.64 & 8.81 & 1928 & 30 & 1958 & 0.9993 \\
\hline A1 & TPI & 48.4 & 8.4 & 5.40 & 8.91 & 1255 & 15 & 1270 & 0.9995 \\
\hline $\mathrm{A} 1$ & HPI & 43.8 & 12.3 & 5.86 & 9.55 & 467 & 22 & 489 & 0.9961 \\
\hline A2 & TPI & 47.3 & 6.9 & 4.96 & 8.68 & 2188 & 10 & 2198 & 0.9989 \\
\hline A2 & HPI & 40.1 & 10.6 & 6.53 & 8.93 & 53 & 33 & 86 & 0.9988 \\
\hline AN & HPO & 50.2 & 3.4 & 5.85 & 8.65 & 122 & 6 & 128 & 0.9996 \\
\hline AN & TPI & 41.4 & 4.9 & 5.81 & 8.59 & 139 & 11 & 150 & 0.9996 \\
\hline AN & HPI & 34.1 & 10.2 & 6.11 & 8.62 & 113 & 15 & 128 & 0.9997 \\
\hline MT & HPO & 46.5 & 3.1 & 5.66 & 9.84 & 224 & 7 & 231 & 0.9982 \\
\hline MT & HPI & 34.2 & 5.5 & 5.84 & 8.81 & 304 & 56 & 360 & 0.9997 \\
\hline
\end{tabular}


Table 3

Zinc speciation (in \%) for each binding site and for each DOM fraction in WWTP effluent at a given total dissolved Zn concentration, $\mathrm{pH} 8$ and DOC $=15 \mathrm{mg}$ C $\mathrm{L}^{-1}$.

\begin{tabular}{|c|c|c|c|c|c|c|c|c|c|c|c|}
\hline \multirow[t]{2}{*}[\mathrm{Zn}]{$_{\text {total }} / \mathrm{\mu g} \mathrm{L}^{-1}$} & \multicolumn{2}{|c|}{$\mathrm{Zn}_{\text {inorganic }}$} & \multicolumn{3}{|c|}{ HPO A1 } & \multicolumn{3}{|c|}{ TPIA1 } & \multicolumn{3}{|c|}{ HPIA1 } \\
\hline & $\mathrm{Zn}^{2+}$ & $\overline{\text { Total }}$ & $\mathrm{L}_{2}$ & $\mathrm{~L}_{1}$ & $\overline{\text { Total }}$ & $\overline{\mathrm{L}_{2}}$ & $\mathrm{~L}_{1}$ & $\overline{\text { Total }}$ & $\mathrm{L}_{2}$ & $\mathrm{~L}_{1}$ & $\overline{\text { Total }}$ \\
\hline 1 & 0.3 & 0.4 & 17.1 & 0.7 & 17.8 & 6.3 & 0.2 & 6.5 & 74.9 & 0.4 & 75.3 \\
\hline 10 & 0.6 & 0.9 & 26.5 & 1.4 & 27.9 & 9.1 & 0.4 & 9.5 & 60.8 & 0.9 & 61.7 \\
\hline 100 & 13.9 & 20.2 & 10.1 & 31.2 & 41.3 & 3.0 & 7.5 & 10.5 & 9.5 & 18.5 & 28.0 \\
\hline
\end{tabular}

et al., 1999; Kraepiel et al., 1997; Naito et al., 2010; Zwolsman et al., 1997).

For the first case with no EfOM, $\mathrm{L}_{2}$ sites controlled zinc speciation at the lower zinc concentration. As zinc concentration increased, these sites became saturated and, consequently, $\mathrm{L}_{1}$ sites bound a slightly higher zinc proportion (2\%-7\%). As a result of the lower stability constant of $\mathrm{L}_{1}$ sites, the inorganic zinc and especially the free zinc highly increased, i.e. from $15 \%$ to $62 \%$ (Table 4 ).

In the second case, which represents the Seine River with urban discharge (EfOM) during a low river flow period, roughly $49 \%$ to $94 \%$ of total zinc was bound to the HPI fraction, mainly through $\mathrm{L}_{2}$ sites at low zinc concentrations ( 10 and $1 \mu \mathrm{g} \mathrm{L}^{-1}$, respectively). EfOM and especially the HPI fraction therefore controlled to a large extent zinc speciation in the Seine. When $\mathrm{Zn}=10 \mu \mathrm{g} \mathrm{L}^{-1}, \mathrm{~L}_{2}$ sites of the HPI fraction became saturated, resulting in a $25 \%$ distribution of total zinc among the $L_{2}$ sites of the HPO fraction and $L_{1}$ sites of the HPI fraction; moreover, the inorganic zinc and especially free zinc increased significantly, from $1 \%$ to $26 \%$ of total zinc. Due to the lower stability constant of HPOM2 binding sites compared to HPIA1 sites, the free zinc proportion is higher (48\%) in the first case than in the second (26\%). When $[\mathrm{Zn}]_{\text {total }}=100 \mu \mathrm{g} \mathrm{L}^{-1}$, organic binding sites were saturated and the inorganic zinc fraction rose above $70 \%$, as previously observed in severely polluted waters (Lourino-Cabana et al., 2010). In comparing these two cases, it can be noted that the presence of EfOM decreases the percentage of free zinc by a factor ranging from 1.2 at $[\mathrm{Zn}]_{\text {total }}=$ $100 \mu \mathrm{g} \mathrm{L}^{-1}$ to 12 at $[\mathrm{Zn}]_{\text {total }}=1 \mu \mathrm{g} \mathrm{L}^{-1}$.

\subsubsection{Consequences for $\mathrm{Zn}$ speciation and bioavailability in urbanized aquatic systems}

As previously discussed, these computations were not intended to be representative of the actual environment, but rather to model the effect of EfOM inputs on zinc speciation in the Seine River. It has been clearly demonstrated, for the first time, that the hydrophilic fraction of EfOM can exert a greater impact on zinc speciation than "natural" HPO DOM sampled upstream from Paris. These results thus highlight that zinc speciation in surface water under high human pressure should include not only the humic and/or fulvic part of DOC but also the other more hydrophilic fractions. In the widely used biotic ligand model (BLM), which predicts the toxicity of metals in aquatic environments, DOC is typically considered to contain an "active" fraction binding metal ions and another fraction that is inert with respect to metal binding. Consequently, the proportion of "active" DOC has a significant impact on modeled metal speciation and toxicity. The active fraction has been found to be variable, between $40 \%$ and $80 \%$ as fulvic acid (Dwane and Tipping, 1998). A default active fraction value of 50\% however is often applied (De Schamphelaere et al., 2002; De Schamphelaere et al., 2003). Furthermore, the use of specific UV absorbance (SUVA) for estimating this active fraction has been shown to improve the accuracy of BLM toxicity forecasts by a factor ranging between 1.3 and 2.0 (Al-Reasi et al., 2012; Al-Reasi et al., 2013; De Schamphelaere et al., 2004; Kramer et al., 2004; Sánchez-Marín et al., 2010). Yet these studies were merely focused on the more hydrophobic fraction of DOM (humic and fulvic substances) and/or on natural DOM not affected by wastewater discharge. These samples mainly display trace metal binding groups (e.g. carboxylic and phenolic) with strong SUVA, such that a strong correlation between SUVA and the "active" DOC fraction could reasonably be expected. However, another study involving effluents (PernetCoudrier et al., 2008) has demonstrated the importance of the hydrophilic fraction in EfOM, which also exhibits strong copper binding properties despite a low SUVA. This feature again suggests that SUVA is unlikely to be useful for predicting metal speciation and toxicity in aquatic systems in the presence of strong urban inputs. Fig. 3 combines the previously determined zinc-binding parameters and the DOM characterization, through the $\mathrm{K}_{1} \mathrm{~L}_{1}$ and $\mathrm{K}_{2} \mathrm{~L}_{2}$ products vs. SUVA for each studied fraction. This figure therefore highlights the strong zinc-binding properties of HPI fractions despite their lower aromatic carbon content and, hence, their lower SUVA compared to more hydrophobic DOM. This finding has also been previously proven for $\mathrm{Pb}$ (Pernet-Coudrier et al., 2011a), Hg (Muresan et al., 2011), Cd, Cu, Ni and Zn (Baken et al., 2011). In this last study, complexation parameters were not determined but a one-step resin-exchange method allows to assess $\mathrm{Zn}$ binding affinity of freshwater dissolved organic matter. Larger metal affinities were found for DOM from waters with urban inputs. Therefore, if hydrophilic DOM is not taken into account in the biotic ligand model, especially in the context of urban waters, bioavailability and metal toxicity could be overestimated. This shows that SUVA is an inaccurate indicator for the DOM impact on zinc speciation in urban waters and moreover underscores the need to take EfOM into account in the BLM so as to better predict trace metal speciation and toxicity. Since nitrogen and sulfur were observed at relatively high concentrations in EfOM (PernetCoudrier et al., 2011b) and found to strongly participate in metal binding (Muresan et al., 2011; Pernet-Coudrier et al., 2011a), then dissolved organic nitrogen and dissolved organic sulfur may offer a means to improve BLM prediction in urban waters.

\section{Conclusion}

This work has focused on the zinc-binding characteristics of dissolved organic matter (DOM) fractions from the Seine River Basin, which is severely impacted by urban discharge downstream of Paris.

Table 4

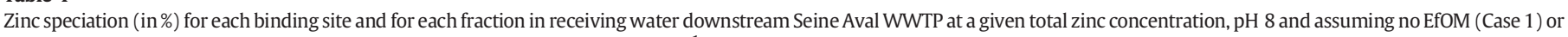
a mixture of 50\% HPOM2 and 50\% HPIA1 from EfOM (Case 2). DOC $=5 \mathrm{mg} \mathrm{C} \mathrm{L}^{-1}$ in both cases.

\begin{tabular}{|c|c|c|c|c|c|c|c|c|c|c|c|c|c|}
\hline \multirow{3}{*}[\mathrm{Zn}]{$_{\text {total }} / \mu \mathrm{g} \mathrm{L} \mathrm{L}^{-1}$} & \multicolumn{5}{|c|}{ Case 1 (no EfOM) } & \multicolumn{8}{|c|}{ Case 2 (with EfOM) } \\
\hline & \multicolumn{2}{|c|}{$\mathrm{Zn}$ inorganic } & \multicolumn{3}{|c|}{ HPOM2 } & \multicolumn{2}{|c|}{$\mathrm{Zn}_{\text {inorganic }}$} & \multicolumn{3}{|c|}{ HPOM2 } & \multicolumn{3}{|c|}{ HPIA1 } \\
\hline & $\mathrm{Zn}^{2+}$ & Total & $\mathrm{L}_{2}$ & $\mathrm{~L}_{1}$ & Total & $\mathrm{Zn}^{2+}$ & Total & $\mathrm{L}_{2}$ & $\mathrm{~L}_{1}$ & Total & $\mathrm{L}_{2}$ & $\mathrm{~L}_{1}$ & Total \\
\hline 1 & 15.0 & 21.8 & 76.2 & 2.0 & 78.2 & 1.2 & 1.8 & 4.3 & 0.1 & 4.4 & 93.1 & 0.7 & 93.8 \\
\hline 10 & 48.2 & 70.1 & 23.7 & 6.2 & 29.9 & 26.1 & 38.0 & 11.2 & 1.7 & 12.9 & 35.1 & 14.0 & 49.1 \\
\hline 100 & 62.4 & 90.8 & 2.5 & 6.7 & 9.2 & 49.8 & 72.4 & 1.3 & 2.7 & 4.0 & 3.6 & 20.0 & 23.6 \\
\hline
\end{tabular}



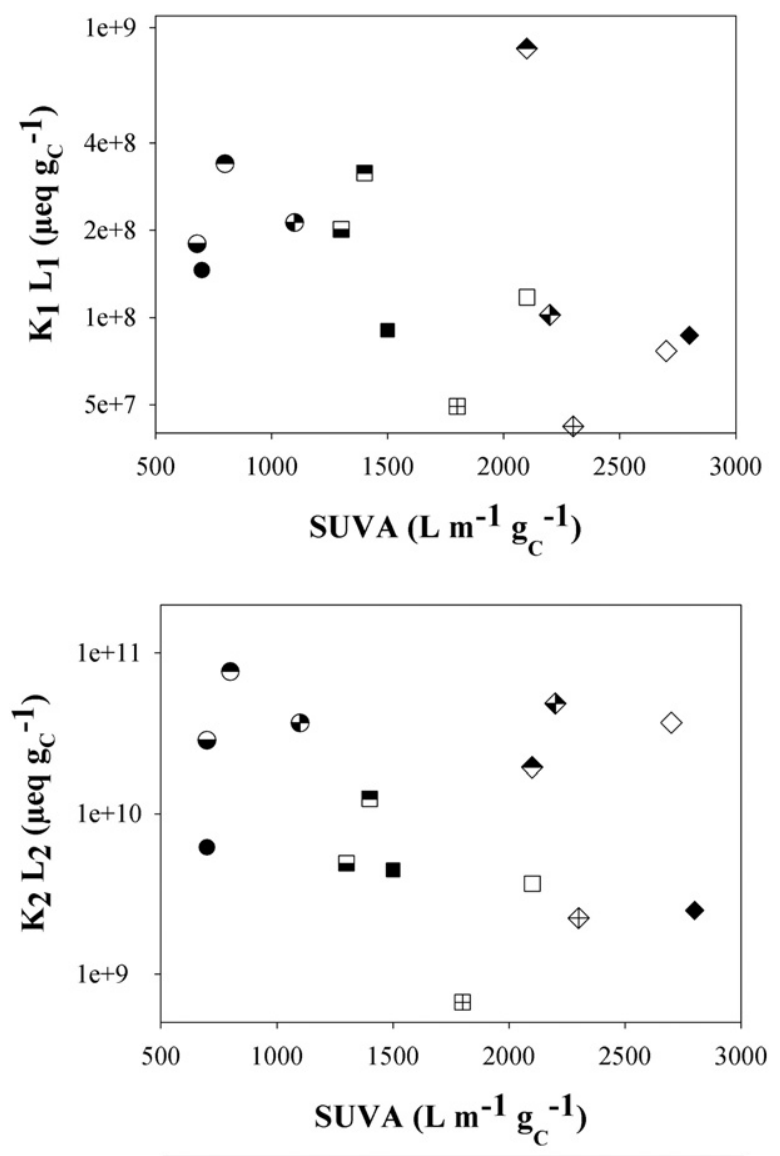

$\diamond$ Hydrophobic DOM
$\square$ Transphilic DOM
Hydrophilic DOM
$\square$ M1 $\mid$ River upstream: "natural" sites
$\square$ M2
A1 |WWTP effluents
$\square$ A2
AN $\mid$ River downstream: impacted sites
MT

Fig. 3. $K_{1} L_{1}$ and $K_{2} L_{2}$ versus specific UV absorbance (SUVA at $254 \mathrm{~nm}$ ) of the studied DOM fractions (SUVA taken from Pernet-Coudrier et al., 2011b).

The DOM fractions were first separated and extracted according to their polarity: hydrophobic, transphilic, and hydrophilic. The applied methodology was based on determining labile zinc species by means of differential pulse anodic stripping voltammetry (DPASV) at increasing concentrations of total zinc on a logarithmic scale and for fixed values of $\mathrm{pH}$, ionic strength and temperature, followed up by modeling with a discrete two-site ligand distribution. The conditional zinc-binding constants $\left(\mathrm{K}_{\mathrm{i}}\right)$ and ligand density $\left(\mathrm{L}_{\mathrm{i}}\right)$ were then determined for each binding site and each studied DOM fraction before further comparison and discussion in terms of the hydrophobic/hydrophilic characteristic and sample origin. Results have highlighted the high zinc-binding properties of effluent organic matter, especially the most hydrophilic fraction, which also displayed very low specific UV absorbance. Although the biotic ligand model takes into account the quality of DOM by incorporating its specific UV-absorbance into the metal bioavailability and toxicity predictions, this correction is not efficient for highly-impacted receiving waters. Further research is thus critical to determining the extent and conditions under which EfOM can exert a major impact in attenuating metal toxicity in waters containing urban inputs.

\section{Acknowledgments}

This work has been financially supported by the French Ministry of Research and Education (through a Ph.D. grant), the French National Research Agency (ANR, project: BIOMET JC05_59809), the DIM Agroscience, Territoires, Ecologie, Alimentation organization, the Île de France Region and France's Ministry of Agriculture (Postdoctoral Fellowship of Yoann Louis). The authors would like to thank the LSCE Laboratory, with special appreciation to Sophie Ayrault and Cindy Priadi for their total zinc analysis using ICP-MS. The authors are also grateful to the SIAAP Interdepartmental Paris Metropolitan Sanitation Group for providing access to the WWTP sampling site.

\section{References}

Al-Reasi H, Scott Smith D, Wood C. Evaluating the ameliorative effect of natural dissolved organic matter (DOM) quality on copper toxicity to Daphnia Magna: improving the BLM. Ecotoxicology 2012;21:524-37.

Al-Reasi HA, Wood CM, Smith DS. Characterization of freshwater natural dissolved organic matter (dom): mechanistic explanations for protective effects against metal toxicity and direct effects on organisms. Environ Int 2013;59:201-7.

Baken S, Degryse F, Verheyen L, Merckx R, Smolders E. Metal complexation properties of freshwater dissolved organic matter are explained by its aromaticity and by anthropogenic ligands. Environ Sci Technol 2011;45:2584-90.

Batley GE, Apte SC, Stauber JL. Speciation and bioavailability of trace metals in water: progress since 1982. Aust J Chem 2004;57:903-19.

Bugarin MG, Mota AM, Pinheiro JP, Gonçalves MLS. Influence of metal concentration at the electrode surface in differential pulse anodic stripping voltammetry in the presence of humic matter. Anal Chim Acta 1994;294:271-81.

Buzier R, Tusseau-Vuillemin MH, Mouchel JM. Evaluation of DGT as a metal speciation tool in wastewater. Sci Total Environ 2006a;358:277-85.

Buzier R, Tusseau-Vuillemin MH, dit Meriadec CM, Rousselot O, Mouchel JM. Trace metal speciation and fluxes within a major French wastewater treatment plant: Impact of the successive treatments stages. Chemosphere 2006b;65:2419-26.

Chaminda GGT, Nakajima F, Kasuga I. Biological alteration of zinc complexation characteristics of dissolved organic matter in domestic wastewater treatment plant effluent under river water environment. J Water Environ Technol 2010;8:403-11.

Cheng T, Allen HE. Comparison of zinc complexation properties of dissolved natural organic matter from different surface waters. J Environ Manage 2006;80:222-9.

Cheng T, Schamphelaere KD, Lofts S, Janssen C, Allen HE. Measurement and computation of zinc binding to natural dissolved organic matter in European surface waters. Anal Chim Acta 2005;542:230-9.

Chiffoleau J-F, Cossa D, Auger D, Truquet I. Trace metal distribution, partition and fluxes in the Seine estuary (France) in low discharge regime. Mar Chem 1994;47:145-58.

Chiffoleau J-F, Auger D, Chartier E. Fluxes of selected trace metals from the seine estuary to the eastern English channel during the period August 1994 to July 1995. Cont Shelf Res 1999;19:2063-82.

Coale KH, Bruland KW. Spatial and temporal variability in copper complexation in the North Pacific. Deep Sea Res A Ocean Res Pap 1990;37:317-36.

De Schamphelaere KAC, Heijerick DG, Janssen CR. Refinement and field validation of a biotic ligand model predicting acute copper toxicity to Daphnia Magna. Comp Biochem Physiol C: Toxicol Pharmacol 2002;133:243-58.

De Schamphelaere KAC, Heijerick DG, Janssen CR. Erratum to "Refinement and field validation of a biotic ligand model predicting acute copper toxicity to Daphnia Magna" [comp. Biochem. Physiol. C 133 (2002) 243-258]. Comp Biochem Physiol C: Toxicol Pharmacol 2003;134:529.

De Schamphelaere KAC, Vasconcelos FM, Tack FMG, Allen HE, Janssen CR. Effect of dissolved organic matter source on acute copper toxicity to "Daphnia Magna". Environ Toxicol Chem 2004;23:1248-55.

Di Toro DM, Allen HE, Bergman HL, Meyer JS, Paquin PR, Santore RC. Biotic ligand model of the acute toxicity of metals. 1. Technical basis. Environ Toxicol Chem 2001;20: 2383-96.

Dwane GC, Tipping E. Testing a humic speciation model by titration of copper-amended natural waters. Environ Int 1998;24:609-16.

Garnier C, Mounier S, Benaim JY. Metal logarithmic scale titration as a tool for complexing ligand distribution determination: an application by DPASV. Environ Technol 2004a; 25:589-99.

Garnier C, Pižeta I, Mounier S, Benäim JY, Branica M. Influence of the type of titration and of data treatment methods on metal complexing parameters determination of single and multi-ligand systems measured by stripping voltammetry. Anal Chim Acta 2004b;505:263-75.

Gromaire MC, Garnaud S, Saad M, Chebbo G. Contribution of different sources to the pollution of wet weather flows in combined sewers. Water Res 2001;35:521-33.

Gromaire MC, Chebbo G, Constant A. Impact of zinc roofing on urban runoff pollutant loads: the case of Paris. Water Sci Technol 2002;45:113-22.

Imai A, Fukushima T, Matsushige K, Kim Y-H, Choi K. Characterization of dissolved organic matter in effluents from wastewater treatment plants. Water Res 2002;36:859-70.

Kandegedara A, Rorabacher DB. Noncomplexing tertiary amines as "better" buffers covering the range of $\mathrm{pH} 3-11$. Temperature dependence of their acid dissociation constants. Anal Chem 1999;71:3140-4.

Kraepiel AML, Chiffoleau J-F, Martin J-M, Morel FMM. Geochemistry of trace metals in the gironde estuary. Geochim Cosmochim Acta 1997;61:1421-36. 
Kramer KJM, Jak RG, van Hattum B, Hooftman RN, Zwolsman JJG. Copper toxicity in relation to surface water-dissolved organic matter: biological effects to Daphnia Magna. Environ Toxicol Chem 2004;23:2971-80.

Louis Y, Cmuk P, Omanović D, Garnier C, Lenoble V, Mounier S, et al. Speciation of trace metals in natural waters: the influence of an adsorbed layer of natural organic matter (NOM) on voltammetric behaviour of copper. Anal Chim Acta 2008;606:37-44.

Louis Y, Garnier C, Lenoble V, Omanovic D, Mounier S, Pizeta I. Characterisation and modelling of marine dissolved organic matter interactions with major and trace cations. Mar Environ Res 2009;67:100-7.

Lourino-Cabana B, Lesven L, Billon G, Proix N, Recourt P, Ouddane B, et al. Impacts of metal contamination in calcareous waters of Deûle river (France): water quality and thermodynamic studies on metallic mobility. Water Air Soil Pollut 2010;206: 187-201.

Ma H, Allen HE, Yin Y. Characterization of isolated fractions of dissolved organic matter from natural waters and a wastewater effluent. Water Res 2001;35:985-96.

Martin-Mousset B, Croué JP, Lefebvre E, Legube B. Distribution et caractérisation de la matière organique dissoute d'eaux naturelles de surface. Water Res 1997;31:541-53.

Matar Z. Influence de la matière organique dissoute d'origine urbaine sur la spéciation et la biodisponibilité des métaux dans les milieux récepteurs anthropisés LEESU. Champs-sur-Marne: Université Paris-Est; 2012.

Muller FLL. Evaluation of the effects of natural dissolved and colloidal organic ligands on the electrochemical lability of $\mathrm{Cu}, \mathrm{Pb}$ and $\mathrm{Cd}$ in the Arran Deep, Scotland. Mar Chem 1999;67:43-60.

Muresan B, Pernet-Coudrier B, Cossa D, Varrault G. Measurement and modeling of mercury complexation by dissolved organic matter isolates from freshwater and effluents of major wastewater treatment plant. Appl Geochem 2011;26:2057-63.

Naito W, Kamo M, Tsushima K, Iwasaki Y. Exposure and risk assessment of zinc in Japanese surface waters. Sci Total Environ 2010;408:4271-84.

Nicolau R, Louis Y, Omanović D, Garnier C, Mounier S, Pižeta I. Study of interactions of concentrated marine dissolved organic matter with copper and zinc by pseudopolarography. Anal Chim Acta 2008;618:35-42.

Omanović D, Garnier C, Louis Y, Lenoble V, Mounier S, Pižeta I. Significance of data treatment and experimental setup on the determination of copper complexing parameters by anodic stripping voltammetry. Anal Chim Acta 2010;664:136-43.

Pernet-Coudrier B, Clouzot L, Varrault G, Tusseau-Vuillemin MH, Verger A, Mouchel JM. Dissolved organic matter from treated effluent of a major wastewater treatment plant: characterization and influence on copper toxicity. Chemosphere 2008;73: 593-9.

Pernet-Coudrier B, Companys E, Galceran J, Morey M, Mouchel J-M, Puy J, et al. Pb-binding to various dissolved organic matter in urban aquatic systems: key role of the most hydrophilic fraction. Geochim Cosmochim Acta 2011a;75:4005-19.

Pernet-Coudrier B, Varrault G, Saad M, Croue JP, Dignac MF, Mouchel JM. Characterisation of dissolved organic matter in parisian urban aquatic systems: predominance of hydrophilic and proteinaceous structures. Biogeochem 2011b;106:89-106.

Robert-Sainte P, Gromaire MC, de Gouvello B, Saad M, Chebbo G. Annual metallic flows in roof runoff from different materials: test-bed scale in Paris conurbation. Environ Sci Technol 2009;43:5612-8.

Sánchez-Marín P, Santos-Echeandía J, Nieto-Cid M, Álvarez-Salgado XA, Beiras R. Effect of dissolved organic matter (DOM) of contrasting origins on $\mathrm{Cu}$ and $\mathrm{Pb}$ speciation and toxicity to paracentrotus lividus larvae. Aquat Toxicol 2010;96:90-102.

Sarathy V, Allen HE. Copper complexation by dissolved organic matter from surface water and wastewater effluent. Ecotoxicol Environ Saf 2005;61:337-44.

Soares HMVM, Conde PCFL. Electrochemical investigations of the effect of $n$-substituted aminosulfonic acids with a piperazinic ring $\mathrm{pH}$ buffers on heavy metal processes which may have implications on speciation studies. Anal Chim Acta 2000;421:103-11.

Sposito G. Trace metals in contaminated waters. Environ Sci Technol 1981;15:396-403.

Thevenot DR, Moilleron R, Lestel L, Gromaire MC, Rocher V, Cambier P, et al. Critical budget of metal sources and pathways in the Seine river basin (1994-2003) for Cd, Cr, $\mathrm{Cu}, \mathrm{Hg}, \mathrm{Ni}, \mathrm{Pb}$ and $\mathrm{Zn}$. Sci Total Environ 2007;375:180-203.

Tipping E. Humic ion-binding model VI: an improved description of the interactions of protons and metal ions with humic substances. Aquat Geochem 1998;4:3-47.

Town RM, Filella M. Dispelling the myths: is the existence of L1 and L2 ligands necessary to explain metal ion speciation in natural waters? Limnol Oceanogr 2000;45: 1341-57.

Tsang JJ, Rozan TF, Hsu-Kim H, Mullaugh KM, Luther GW. Pseudopolarographic determination of $\mathrm{Cd}^{2+}$ complexation in freshwater. Environ Sci Technol 2006:40:5388-94.

van Leeuwen HP, Town RM, Buffle J, Cleven RFMJ, Davison W, Puy J, et al. Dynamic speciation analysis and bioavailability of metals in aquatic systems. Environ Sci Technol 2005;39:8545-56.

Zwolsman JJG, Van Eck BTM, Van Der Weijden CH. Geochemistry of dissolved trace metals (cadmium, copper, zinc) in the Scheldt estuary, southwestern Netherlands: impact of seasonal variability. Geochim Cosmochim Acta 1997;61:1635-52. 